\title{
Spectral Analysis of a Core from the Sebkha of Sidi Mansour, Southern Tunisia: The Holocene Cyclostratigraphy
}

\author{
Elhoucine Essefi, Najoua Gharsalli, Sabrine Kalabi, Mohamed Ben Ameur and Chokri Yaich
}

Sedimentary Dynamics and Environment (DSE) (Code 03/UR/10-03), National Engineering School of Sfax, University of Sfax, Tunisia

\begin{abstract}
The Milancovitch Theory explaining the ancient cyclostratigraphy does not file a case for the Holocene cyclostratigraphy. Instead, other astronomical and oceanographic mechanisms control the cyclicity within Holocene sediment. This work aimed to find out the climatic cyclicity along a core from the sebkha of Sidi Mansour located along the Mediterranean coast in Tunisia, through using different proxies: the magnetic susceptibility, carbonate percentages and chemical elements $(\mathrm{Ca}, \mathrm{Na}$, and $\mathrm{K}$ ). Based on previous radiocarbon and tephrochrnological dating in the study area, the core was estimated to cover the two last millennia with a sedimentation rate of $0.35 \mathrm{~mm} / \mathrm{yr}$. This rate allows the elaboration of a depth-age model to carry the spectral analysis. Not all the proxies visualize the same climatic cycles. For instance, the spectral analysis of the magnetic susceptibility and Sodium data visualized a 1000 yr cycle. The spectral analysis of Potassium data did not visualize significant cycles. The spectral analysis of the carbonate percentages and calcium data visualized dual cycles of 1700-700 yr and 493-329 yr respectively. The about $500 \mathrm{yr}$ and $1000 \mathrm{yr}$ cycles are related to Sun activity. Other oceanographic and atmospheric factors could generate other cycles of $1700 \mathrm{yr}, 700 \mathrm{yr}, 493 \mathrm{yr}$, and $329 \mathrm{yr}$. The majority of these cycles were worldwide recorded as interplay between the oceanography and the solar forcing. Contrary to the earth-driven cyclostratigraphy related to orbital parameters and geographical positions, the Holocene cyclostratigraphy is sun-driven.
\end{abstract}

Keywords: Sun-driven cyclostratigraphy; Holocene; Sebkha of Sidi Mansour; Southern Tunisia

\section{Introduction}

\section{Sun activity and its effect on climatic cyclicity}

The Milancovitch Theory explaining the ancient (e.g., Cretaceous and Miocene) cyclostratigraphy does not file a case for the Holocene cyclostratigraphy. For instance, the decadal to millennial scales cycles of the Late Holocene sediment in lakes and sebkhas recorded based on geophysical and geochemical parameters were less than likely explained by this Theory. Instead, other astronomical and oceanographic causes have been recently highlighted to explain short climatic cycles [1-6]. As a matter of fact, Sun activity and its effect on climatic cyclicity have gained univoqual popularity. The short term cyclicity of Sun activity is inferred through sunspots number and activity. The Schawbe cycle ( 9 to $14 \mathrm{yr}$ with an average of $11 \mathrm{yr}$ ) [7-9] is governed by the Sun internal dynamics whereas the $22 \mathrm{yr}$ Hale cycle is linked to solar convection [10]. The Gleissberg cycle $(87 \mathrm{yr})$ is due to the variability in Sun diameter [11]. Other cycles such as that of Vriès $(210 \mathrm{yr})$ are still unknown [12]. These cycles are directly seen through telescopic sunspots and historical naked-eye sunspots observations of solar activity. Other proxies including the cosmogenic isotope $10 \mathrm{Be}$, cosmogenic isotope $14 \mathrm{C}$ and the climate record allows inferring the longer cyclicity of Sun activity [7-12 and reference therein]. Nonetheless, climatic cyclicities are not always related to Sun activity. Instead, other oceanographic and atmospheric mechanisms and processes created hybrid cycles [6]. For instance, in the westernmost Mediterranean Sea, major periodicities at $1300 \mathrm{yr}$ and $1515 \mathrm{yr}$, linked with North Atlantic climate variability and the African monsoon system were found out along the past 20,000 yr. Other major periodicities of $2000 \mathrm{yr}$ and $5000 \mathrm{yr}$ are related to solar activity. Minor secondary millennial to centennial cycles stretching along $650 \mathrm{yr}, 1087 \mathrm{yr}$, and $3000 \mathrm{yr}$ are still unknown [13]. In this work, the aim was studying the Holocene cyclostratigraphy along a core from an endorheic system (sebkha Sidi Mansour) located at the coast of the Mediterranean Sea.
Study area: The Golf of Gabes within a Mediterranean Sea and Atlantic Ocean connection

The focus on the Mediterranean regions is due to its sensitivity to global climate changes as result of being a semi-enclosed basin [6]. The Mediterranean Sea is hydrologically and climatically depending on the Atlantic Ocean. During the few geological periods in which it behaves as a stand-alone basin, such as the Messinian Salinity Crisis, the Mediterranean Sea totally dried and its coastal regions were dominated by an arid climate [14]. Currently, the Atlantic Ocean feeds it with constant quantities of water through Gibraltar (Figure 1a). This connection ensures that the climate at coasts (exoreic and endorheic systems) of the Mediterranean Sea is controlled by solar activity as well as the oceanographic circulation. Depending on their geographical position, relative to the sea, we can distinguish three kinds of systems: exoreic (e.g., Chaffar system), semi-exoreic (e.g., El-Guettiate) and endorheic (e.g., Sidi Mansour and Mhabeul sebkhas) systems (Figure 1b). The exoreic systems are regarded as coastal marine processes having close relation with the sea, whereas endorheic systems never have a link to the sea due to the uplifted reliefs avoiding any contact. On the other hand, semi-exoreic systems consist of a continental side out of reach of sea water and a marine side occasionally or permanently covered by water.

*Corresponding author: Elhoucine Essefi, Sedimentary Dynamics and Environment (DSE) (Code 03/UR/10-03), National Engineering School of Sfax, Road of Soukra, km 4 Zip Code 3038, University of Sfax, Code-0329, Tunisia, Tel: 21674274 862; E-mail: hocinsefi@yahoo.fr

Received January 22, 2015; Accepted February 24, 2015; Published March 02 , 2015

Citation: Elhoucine Essefi, Najoua Gharsalli, Sabrine Kalabi, Mohamed Ben Ameur and Chokri Yaich (2015) Spectral Analysis of a Core from the Sebkha of Sidi Mansour, Southern Tunisia: The Holocene Cyclostratigraphy. J Remote Sensing \& GIS 4: 141. doi:10.4172/2469-4134.1000141

Copyright: (c) 2015 Elhoucine Essefi et al. This is an open-access article distributed under the terms of the Creative Commons Attribution License, which permits unrestricted use, distribution, and reproduction in any medium, provided the original author and source are credited. 
Citation: Elhoucine Essefi, Najoua Gharsalli, Sabrine Kalabi, Mohamed Ben Ameur and Chokri Yaich (2015) Spectral Analysis of a Core from the Sebkha of Sidi Mansour, Southern Tunisia: The Holocene Cyclostratigraphy. J Remote Sensing \& GIS 4: 141. doi:10.4172/24694134.1000141

Page 2 of 5

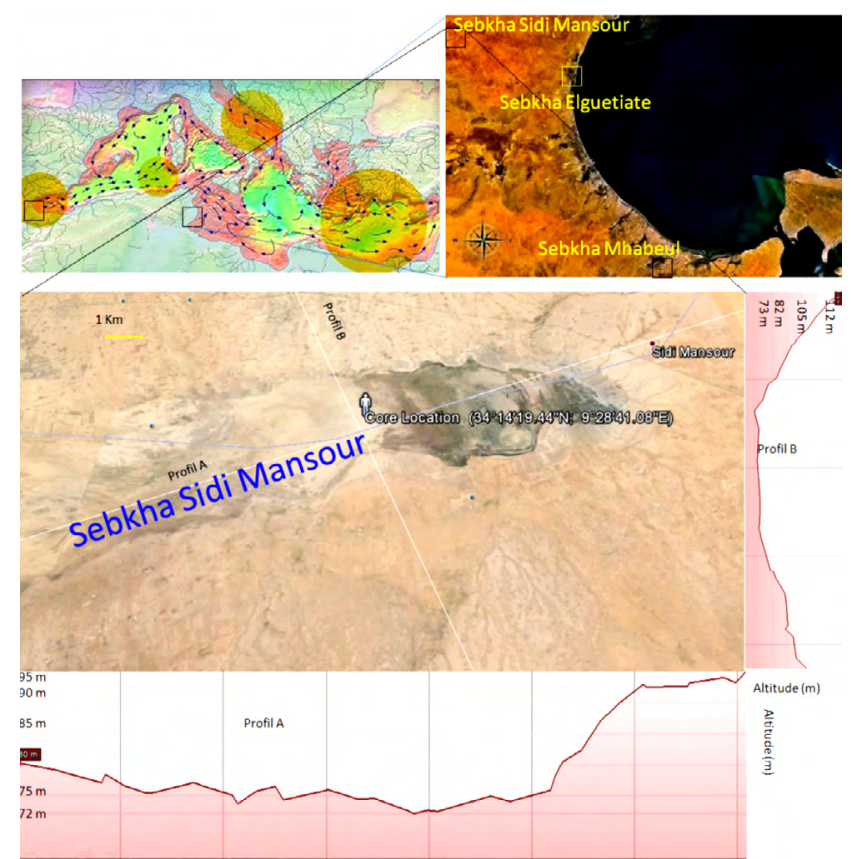

Figure 1: Sidi Mansour sebkha within the framework of a Mediterrenan and Atlantic connection.

The sebkha of Sidi Mansour is located in the south of Tunisia, belonging to the Gafsa governorate. It is an inland system which is characterized by a semi arid climate. The topographic profiles (Figure $1 \mathrm{c}$ and $1 \mathrm{~d}$ ) show an average attitude ranging between $70 \mathrm{~m}$ and $85 \mathrm{~m}$. The sebkha El-Guettiate is located on the coastline of southeast Tunisia. It is a semi-inland system having continental and marine sides. In this work, we use the dating core to estimate the depth-age model at sebkha Sidi Mansour. The 4- $\mathrm{km}^{2}$ sebkha Mhabeul is located on the northern edge of the coastal Djeffara plain (Figure 1b). The sebkha is disjointed from the eastern larger sebkha of Melah by an accumulation of upper Pleistocene sediments, which avoid any connection of the former to the sea. Its sedimentation mode is mainly controlled by precipitation and runoff from small hydrographic networks. This sebkha was also used to estimate the depth-age model at sebkha Sidi Mansour.

\section{Methods and Materials}

During field expeditions, an $80 \mathrm{~cm}$ core was carried out in the sebkha of Sidi Mansour (Figure 1e). Within laboratory, the sampling was carried out each $0.5 \mathrm{~cm}$ to obtain 160 samples. Then, we carry out the measurement of the magnetic susceptibility $\mathrm{MS}, \mathrm{CaCO}_{3}$ percentage and concentrations of chemical elements.

As geophysical parameters, magnetic properties of soils are differently used in earth and environmental sciences. High values of the magnetic susceptibility are attributed to a continental depositional of ferrimagnetic and ferromagnetic minerals such as clayey minerals. Low values of the magnetic susceptibility due to the sedimentation of diamagnetic minerals such as carbonate and quartz. The low frequency MS were measured by the Bartington MS2B probe in the laboratory of Sedimentary Dynamics and Environment, National engineering School of Sfax. The samples were packed into $10 \mathrm{~cm}^{3}$ cylindrical perspex pots for MS analysis. The carbonate percentage is the measuring of $\mathrm{CaCO}_{3}$ percentage in sediment by Bernard calcimeter. Chemical elements including $\mathrm{K}, \mathrm{Na}$, and $\mathrm{Ca}$ were measured by Flame Photometer. To interpret results, we started first by introducing the geochemical convolution. The sodium has always the higher percentage than calcium and potassium with coefficient of ten as indicated in works of Tagorti et al. $[15,16]$. Therefore, to improve the significance of the minor fraction on the identification of climatic change condition, we supposed the convolution term which has as mathematical definition the equation below:

Convolution term $=($ calcium rate $\times 10)+($ potassium rate $\times$ 10)+(sodium rate) $(1)$

As for data treatment, the simple spectral analysis and sinusoidal fitting was carried out through PAST software. Concerning the spectral analysis, PAST includes the Lomb periodogram algorithm for unevenly sampled data [17], with time values given in the first column and dependent values in the second column. The data are automatically detrended prior to analysis. The highest peak in the spectrum is presented with its frequency and power value, together with a probability that the peak could occur from random data. The 0.01 and 0.05 significance levels are shown as dashed lines. For the time series analysis, we need dating to find out temporal climatic cycles. In our present work, we have no precise dating. Nonetheless, the rate of sedimentation in endorheic Tunisian saline systems may be estimated based on the dating of cores collected from sebkhas of the same region namely the sebkhas of Mhabeul and El-Guettiate (Figure 1b). For instance, tephrochronological dating indicated that the rate of sedimentation during the Late Holocene at sebkha Mhabeul was in the range of $0.33 \mathrm{~mm} / \mathrm{yr}$ [3] and $0.37 \mathrm{~mm} / \mathrm{yr}$ [18]. In the continental side of sebkha of El-Guettiate, the radiocarbon dating indicated that the rate of sedimentation during the Late Holocene was in the range of 0.32 $\mathrm{mm} / \mathrm{yr}[19]$ and $0.38 \mathrm{~mm} / \mathrm{yr}$ [20]. Based on mean rate of sedimentation of $0.35 \mathrm{~mm} / \mathrm{yr}$, we can adopt an age-depth model to carry out the temporal spectral analysis in sebkha Sidi Mansour.

The Principal Component Analysis PCA of the magnetic susceptibility MS, carbonate percentage $\mathrm{CaCO}_{3}$, calcium $\mathrm{Ca}$, and sodium $\mathrm{Na}$ and potassium $\mathrm{K}$ rates was computed and plotted in the plane of the first two statistical factors.

\section{Results and Discussion}

Values of the magnetic susceptibility along the core from the sebkha of Sidi Mansour show 2 obvious cycles (Figure 2). The first stretches on $45 \mathrm{~cm}$; it consists of two parts. The first part $(25 \mathrm{~cm})$ is characterized by a downward increasing of the magnetic susceptibility due to the coming of ferromagnetic and ferrimagnetic minerals from continental vicinity. As it was proven by Boyle et al. [21], we can interpret this increase in magnetic susceptibility as a result of wet climatic conditions, which are the responsible agent for reaching the sebkha by an amount of detritic material via Wadis. This amount may be originated from Djbels surrounding the sebkha system which is considered as depression or local base level receiving sediment supply. The second part ranging from 25 to $45 \mathrm{~cm}$ is characterized by low values of magnetic susceptibility, due to the deposition of diamagnetic mineral like carbonate. Thus, a dry period is accountable for this drop which allows the sedimentation of diamagnetic minerals. A second cycle stretches to the bottom of the core.

Along the core, the percentage of $\mathrm{CaCO}_{3}$ presents a fluctuation and values ranging between 10 and 30 percent (Figure 2). Indeed, the first 35 centimeters are characterized by a high percentage of carbonate with average rate of $25 \%$. The second interval stretches until $50 \mathrm{~cm}$ characterized by a decrease in carbonate percentage. To the end of the core, the first and second intervals are repeated as indication of the 
Citation: Elhoucine Essefi, Najoua Gharsalli, Sabrine Kalabi, Mohamed Ben Ameur and Chokri Yaich (2015) Spectral Analysis of a Core from the Sebkha of Sidi Mansour, Southern Tunisia: The Holocene Cyclostratigraphy. J Remote Sensing \& GIS 4: 141. doi:10.4172/24694134.1000141

Page 3 of 5

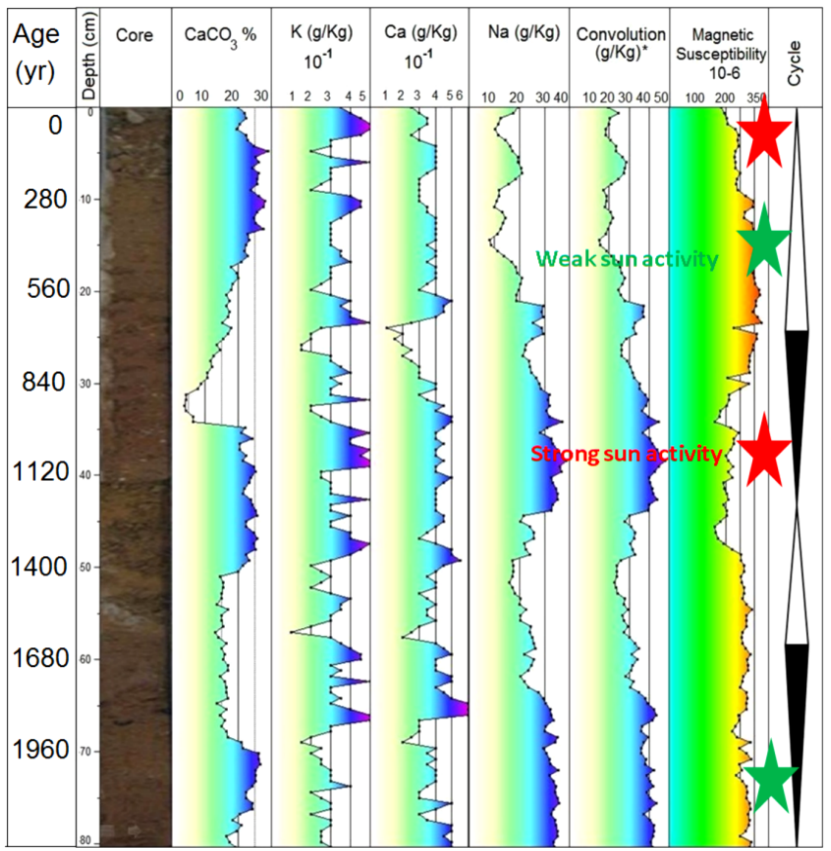

Figure 2: Evolution of magnetic susceptibility, carbonate percentage and geochemical elements along the core of Sidi Mansour sebkha.

setting of the conditions revealing at the top of the core. We note that the variation in carbonate percentage is probably due to Sun activity. Thus, high values are indicated of arid climate, whereas low values are indicators of humid climate.

The geochemical study dealt on three elements: sodium, calcium and potassium. Indeed, the results prove that sodium is the most representative elements, whereas calcium and sodium exist with minor proportions. The calcium rate shows a little variation as indicated (Figure 2) and values range between 0.2 and $0.6 \mathrm{~g} / \mathrm{kg}$. Thus, the proportions along the core are very low unlike the carbonate percentage which presents a relative high rate. Therefore, we could say that the rate of calcium is not only related with carbonate, while it could also be probably linked to the existence of gypsum fraction (CaSO4). Along the core, the proportion of potassium $(\mathrm{K})$ presents low values that range from 0.1 to $0.5 \mathrm{~g} / \mathrm{Kg}$ with slight fluctuation. This fraction is probably due to the existence of $\mathrm{KCl}$. Values of sodium content show an obvious oscillation. Thus, the rate of sodium presents two intervals of decrease which stretch between $0-25 \mathrm{~cm}$ and $43-60 \mathrm{~cm}$, characterized by an important amount of sodium with average of $30 \mathrm{~g} / \mathrm{Kg}$. Between these two intervals, we note a increase in the sodium proportion and values exceed $30 \mathrm{~g} / \mathrm{Kg}$. At the end of the cores, this interval is repeated as indication of periodicity. We deduce then that rate of $\mathrm{Na}$ had a close link with precipitation of salt mineral $(\mathrm{NaCl})$, thus, the periodicity shown in the graphic is probably due to change in climatic conditions which explain the fluctuation of sodium rate. Subsequently, oscillation may results from period of Sun activity. Indeed, in arid period we distinguished a precipitation of high amount of $(\mathrm{NaCl})$, while in humid period the decrease in the rate of salt can be identified.

Along the core, the convolution term shows a significant fluctuation. Thus values allow subdividing the curve on 4 parts. The first part stretches on $20 \mathrm{~cm}$, characterized by low values, ranging around 20 $\mathrm{g} / \mathrm{kg}$. The second part, stretching on $23 \mathrm{~cm}$, presents an increase in the rate and values ranged around $40 \mathrm{~g} / \mathrm{Kg}$. The third and the fourth part show respectively a similar evolution to the first and the second parts.

\section{Cyclostratigraphy based on the magnetic susceptibility and $\mathrm{CaCO}_{3}$ percentages}

The cyclicity obviously identified along the core may be found out through the spectral analysis of data of the different parameters. First, the spectral analysis of Potassium data did not visualize significant cycles. The spectral analysis of data of the magnetic susceptibility shows the individualization of a cycle stretching along about $1000 \mathrm{yr}$ (Figure 3a). Within sebkha Mhabeul, the about $1000 \mathrm{yr}$ cycle was found out based on the magnetic susceptibility data [3]. This also confirms the age-depth model used to estimate the dating at sebkha Sidi Mansour. On the other hand, the spectral analysis of data of the carbonate percentages shows the individualization of two cycles stretching along about $1700 \mathrm{yr}$ and $700 \mathrm{yr}$ (Figure $3 \mathrm{~b}$ ). The $700 \mathrm{yr}$ cycle is barely ascribed to the second harmonic of the $1500 \mathrm{yr}$ cycle in oceanic thermohaline circulation [22]. This cycle may also indicate a tight linkage between the Indian Ocean and African rainfall, and could result from coupled ocean-atmosphere variability inherent to the tropical monsoon system [23]. As for the $1700 \mathrm{yr}$ cycle, [24] highlighted a $1660 \mathrm{yr}$ frequency based the study of sediment color as a proxy of carbonate content. This is also confirmed along a core from Iceland with a 1700-years cycle in the Emiliania Huxleyi concentration record, a proxy of surface hydrology [25].

\section{Cyclostratigraphy based on chemical elements $\mathrm{Ca}$ and $\mathrm{Na}$}

Ca was used as proxy for the presence of the two first precipitated evaporitic minerals calcite and gypsum. Na was used as a proxy for
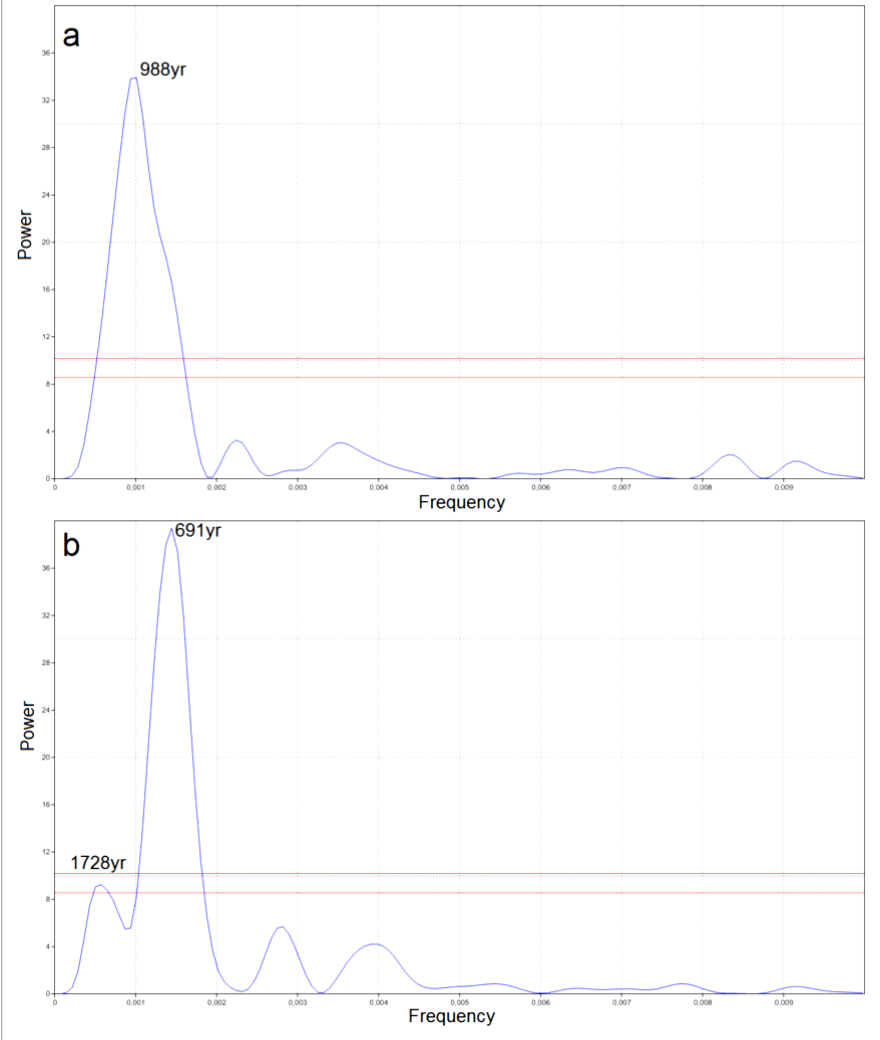

Figure 3: Spectral analysis based on the magnetic susceptibility (a) and $\mathrm{CaCO} 3$ amount (b) 
Citation: Elhoucine Essefi, Najoua Gharsalli, Sabrine Kalabi, Mohamed Ben Ameur and Chokri Yaich (2015) Spectral Analysis of a Core from the Sebkha of Sidi Mansour, Southern Tunisia: The Holocene Cyclostratigraphy. J Remote Sensing \& GIS 4: 141. doi:10.4172/24694134.1000141

available moisture because the principal source of $\mathrm{Na}$ is plagioclase feldspar that is easily decomposed by hydrolysis with sufficient available moisture, releasing $\mathrm{Na}[26]$. The spectral analysis based on Sodium shows the individualization of a cycle stretching along about $1000 \mathrm{yr}$ (Figure 4). On the other hand, the spectral analysis based on Calcium shows the individualization of two cycles stretching along about 500 yr and $350 \mathrm{yr}$ (Figure $3 \mathrm{~b}$ ). The about 500 years was recorded in many other studies [27]. But a cyclicity of about $350 \mathrm{yr}$ was never recorded in the literature.

The Principal Component Analysis of different parameters PCA (factor $1 \times$ factor2) of five parameters (Figure 5) magnetic susceptibility, carbonate percentage, calcium, and sodium and potassium rate of Sidi Mansour sebkha proves that magnetic susceptibility is anticorrelated with rate of sodium, the convolution term and the carbonate percentage. The PCA has proven that climatic variability shown in magnetic susceptibility as indicator of climatic change can be explained by the fluctuation of carbonate percentage. Indeed, during the humid period, the sediment supply coming from continental vicinity through hydrographic network increase the rate of magnetic material and causes the dissolution of $\mathrm{CaCO}_{3}$ and salt mineral . While during arid period, a decrease in values of MS due to the deposition of diamagnetic material such as carbonate and quartz, whereas the $\mathrm{CaCO}_{3}$ percentage, and halite mineral rate shown a significant increase is explained by the drop of stream and river activity.

\section{Conclusion}

The study of the sebkha Sidi Mansour, considered as inland system along the Mediterranean coast, through the investigation of magnetic susceptibility, carbonate percentage, and geochemical elements, show
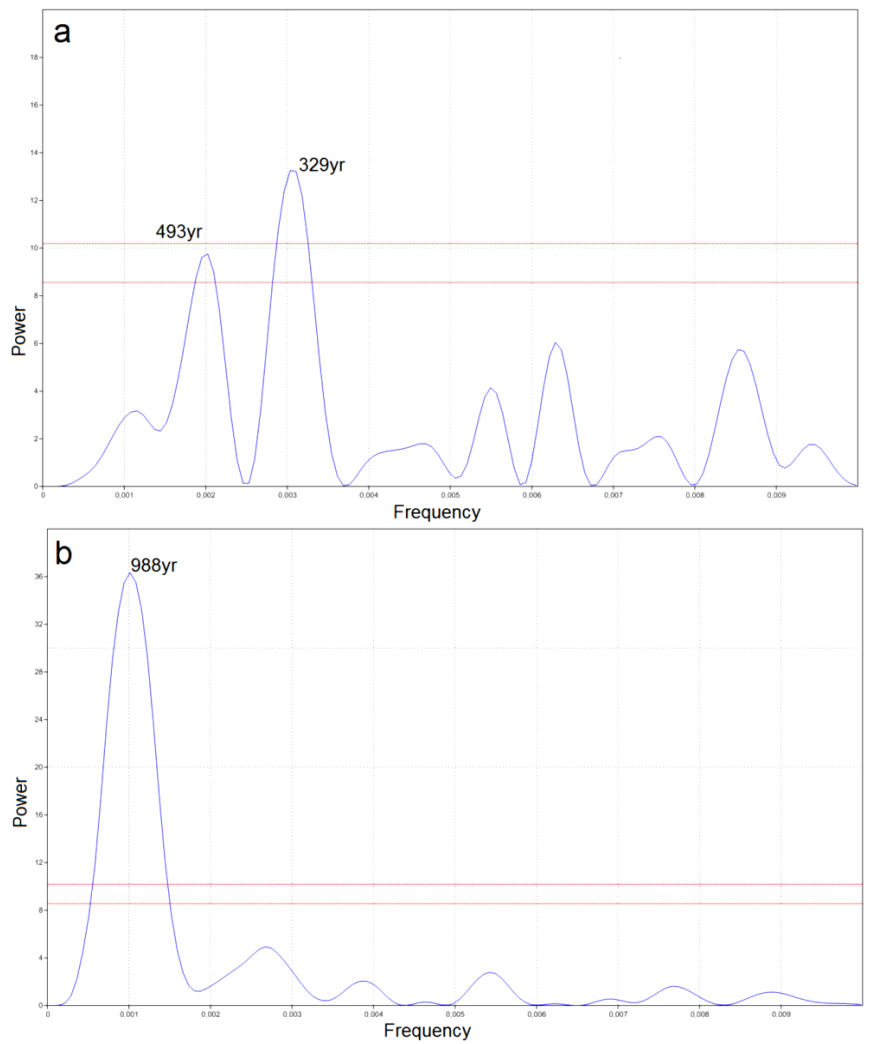

Figure 4: Spectral analysis based on the $\mathrm{Ca}$ and $\mathrm{Na}$ contents.

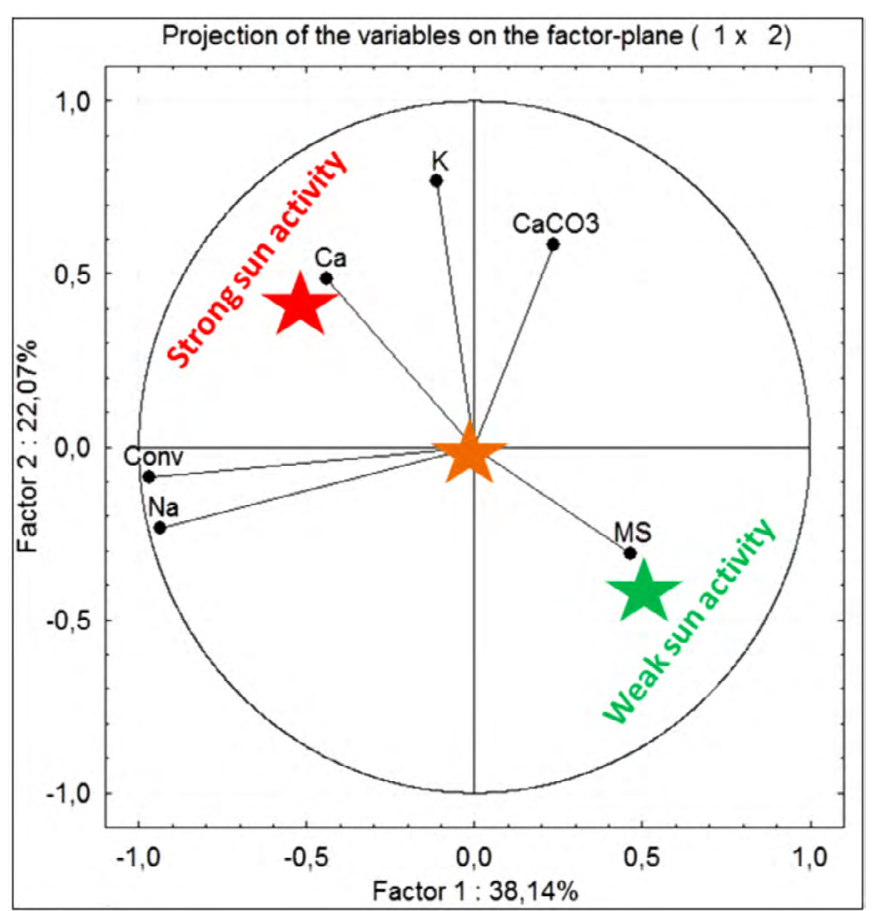

Figure 5: Principal Component Analysis of $\mathrm{MS}, \mathrm{CaCO}, \mathrm{Na}, \mathrm{Ca}, \mathrm{K}$.

the identification different climatic cycles. The spectral analysis of the magnetic susceptibility and Sodium data visualized a $1000 \mathrm{yr}$ cycle. Potassium data did not visualize significant cycles. The spectral analysis of the carbonate percentages and calcium data visualized dual cycles of 1700-700 yr and 493-329 yr respectively. Sun activity generated 500 $\mathrm{yr}$ and $1000 \mathrm{yr}$ cycles whereas the oceanographic circulation between the Atlantic Ocean and the atmospheric link between the Indian Ocean and African rainfall generated other cycles of $1700 \mathrm{yr}$ and 700 yr. The 329-350 yr cycle has never been discussed in the literature; it may be an artifact. Nonetheless, further coming studies should verify and deny the presence of this cyclicity. Nonetheless, the majority of recorded Holocene cycles were worldwide recorded regardless of the geographical position. Contrary to the earth-driven cyclostratigraphy advocated by the Milancovitch Theory, the Holocene cyclostratigraphy is sun-driven since it is mainly governed by the Sun and has no relation with terrestrial orbital parameters and geographical positions.

\section{References}

1. Baumgarten H, Wonik T (2014) Cyclostratigraphic studies of sediments from Lake Van (Turkey) based on their uranium contents obtained from downhole logging and paleoclimatic implications. International Journal of Earth Sciences $1-16$.

2. Timothy PR, Swindles GT (2014) Influence of ocean-atmospheric oscillations on lake ice phenology in eastern North America. Climate Dynamics 1-16.

3. Essefi E, Mefteh S, Medhioub M, Yaich C (2014) Magnetic Study of the Heated and Unheated Sedimentary Fillings of Sebkha Mhabeul, Southeast Tunisia: a Geophysical Method for Paleoclimatic Investigation and Tephrochronological Dating. International Journal of Geophysics.

4. Essefi E, Gharsalli N, Yaich C (2015) Geophysical and Geochemical Study of the Silico-evaporitic Sedimentary Filling of Boujmal wetland, Eastern Tunisia: Inferring the Climatic Signal within Groundwater Noise. Journal of Basic and Applied Research International. In Press.

5. Essefi E, Gharsalli N, Salhi S, and Yaich C (2015) Cyclicity of Grain Size Parameters along a Core from the Gleysol of Sebkha Ennoual, Southeastern Tunisia. Journal of Basic and Applied Research International. IN PRESS. 
Citation: Elhoucine Essefi, Najoua Gharsalli, Sabrine Kalabi, Mohamed Ben Ameur and Chokri Yaich (2015) Spectral Analysis of a Core from the Sebkha of Sidi Mansour, Southern Tunisia: The Holocene Cyclostratigraphy. J Remote Sensing \& GIS 4: 141. doi:10.4172/24694134.1000141

Page 5 of 5

6. Martinez-Ruiz F, Kastner M, Gallego-Torres D, Rodrigo-Gámiz M, NietoMoreno V, Ortega-Huertas M (2015) Paleoclimate and paleoceanography over the past 20,000 yr in the Mediterranean Sea Basins as indicated by sediment elemental proxies. Quaternary Science Reviews 107: 25-46.

7. Deng LH, Li B, Xiang YY, Dun GT (2015) Multi-scale analysis of coronal Fe xiv emission: The role of mid-range periodicities in the Sun heliosphere connection. Journal of Atmospheric and Solar-Terrestrial Physics 122: 18-25.

8. Miyake F, Suzuki A, Masuda K, Horiuchi K, Motoyama H, Matsuzaki H, Nakai Y (2015) Cosmic ray event of AD 774-775 shown in quasi-annual 10Be data from the Antarctic Dome Fuji ice core. Geophysical Research Letters

9. Ahluwalia H S, Ygbuhay R C (2015) Cosmic Ray 11-Year Modulation for Sunspot Cycle 24. Solar Physics 290: 635-643.

10. Sun X, Hoeksema J T, Liu Y, Zhao J (2015) On Polar Magnetic Field Reversal and Surface Flux Transport During Solar Cycle 24. The Astrophysical Journal 798: 114.

11. Kim B, Lee J, Yi Y, Oh S (2015) Variations of solar, interplanetary, and geomagnetic parameters with solar magnetic multipole fields during Solar Cycles 21-24. Advances in Space Research 55: 401-406.

12. Herrera V V, Mendoza B, Herrera, G V (2015) Reconstruction and prediction of the total solar irradiance: From the Medieval Warm Period to the 21 st century. New Astronomy 34: 221-233.

13. Rodrigo-Gámiz M, Martínez-Ruiz F, Rampen SW, Schouten S, Sinninghe Damsté JS (2014). Sea surface temperature variations in the western Mediterranean Sea over the last $20 \mathrm{kyr}$ : A dual-organic proxy (UK' 37 and LDI) approach. Paleoceanography 29: 87-98.

14. Essefi E, Touir J, Tagorti MA, Yaich C (2014) Geodynamic framework of saline systems in eastern Tunisia: saline depressions inherited from the Triassic intrusions and/or the Messinian Salinity Crisis. ISRN GEOLOGY.

15. Tagorti M A, Essefi E, Touir J, Yaich C (2013) Geochemical controls of groundwaters upwelling in saline environments: Case study the discharge playa of Sidi El Hani (Sahel, Tunisia). Journal of African Earth Sciences 86: 1-9.

16. Tagorti M A, Guellala R, Gallala W, Essefi E, Tlig S (2013). Geochemical and hydrogeological studies of a sodium sulphate deposits: the case of Sabkhet $E$ Ghine Oum El Khialate, southeast Tunisia. Carbonates and Evaporites Journal.
17. Press WH, Teukolsky SA, Vetterling WT, Flannery BP (1992) Numerica Recipes in C. Cambridge University Press.

18. Marquer L, Pomel S, Abichou A, Schulz E, Kaniewski D, Van Campo E, (2008) Late Holocene high resolution palaeoclimatic reconstruction inferred from Sabkha Mhabeul, southeast Tunisia. Quaternary Research 70: 240-250.

19. Zaîbi C (2011) Paléoenvironnements Forçages et événements extrêmes associés, à l'emplacement de la côte sud de la Skhira au cours de l'holocène: apport des ostracodes et des foraminifères. PhD Thesis. Faculty of Sciences of Sfax.

20. Gargouri Z (2011) Etude sedimentologique et radiochronologique des dépôts du domaine paralique dans le golf de Gabes (Sebkha El-Guettiate - Sebkha Dreiaa). PhD Thesis. Faculty of Sciences of Sfax.

21. Boyle JF, Dearing JA, Blundell A, Hannam JA (2010) Testing competing hypotheses for soil magnetic susceptibility using a new chemical kinetic model. Geology 38: 1059-1062.

22. Jian Z, Wang P, Saito Y, Wang J, Plaumann U, Oba T, Cheng X (2000) Holocene variability of the Kuroshio Current in the Okinawa Trough, northwestern Pacifc Ocean. Earth and Planetary Science Letters 184: 305-319.

23. Russell, JM, Johnson, TC (2005) A high-resolution geochemical record from Lake Edward, Uganda Congo and the timing and causes of tropical African drought during the late Holocene. Quaternary Science Reviews 24: 1375-1389.

24. Chapman M R, Shackleton N (2000) Evidence of 550-year and 1500-year cyclicities in North Atlantic circulation pattern during the Holocene. The Holocene 10: 287-291.

25. Giraudeau J, Cremer M, Manthè S, Labeyrie L, Bond G (2000) Coccolith evidence for instabilities in surface circulation south of Iceland during Holocene times. Earth Planet. Sci. Lett 179: 257-268.

26. Dean, WE (1997) Rates, Timing, and Cyclicity of Holocene Eolian Activity in North-Central United States: Evidence from Varved Lake Sediments". USGS Staff. Published Research. Paper 300.

27. Carcaillet C, Bouvier M, Fréchette B, Larouche A C, Richard PJH (2001) Comparison of pollen-slide and sieving methods in lacustrine charcoal analyses for local and regional fire history. The Holocene 2001 11: 467. 